\title{
The Transcriptome of Utricle Hair Cell Regeneration in the Avian Inner Ear
}

\author{
Yuan-Chieh Ku, ${ }^{1}$ Nicole A. Renaud, ${ }^{1}$ Rose A. Veile, ${ }^{1}$ Cynthia Helms, ${ }^{1}$ Courtney C.J. Voelker, ${ }^{2}$ Mark E. Warchol, ${ }^{2}$ \\ and Michael Lovett ${ }^{1}$ \\ ${ }^{1}$ Department of Genetics and 2Department of Otolaryngology, Washington University School of Medicine, St Louis, Missouri 63110
}

\begin{abstract}
Sensory hair cell loss is the major cause of hearing and balance disorders. Mammals are incapable of sustained hair cell regeneration, but lower vertebrates can regenerate these mechano-electrical transducers. We present the first comprehensive transcriptome (by mRNASeq) of hair cell regeneration in the chick utricle. We provide pathway and pattern annotations and correlate these with the phenotypic events that occur during regeneration. These patterns are surprisingly synchronous and highly punctuated. We show how these patterns are a new resource for identifying components of the hair cell transcriptome and identify 494 new putative hair-cell-specific genes and validate three of these (of three tested) by immunohistochemical staining. We describe many surprising new components and dynamic expression patterns, particularly within NOTCH signaling. For example, we show that HES7 is specifically expressed during utricle hair cell regeneration and closely parallels the expression of HES5. Likewise, the expression of $A T O H 1$ is closely correlated with $H E Y L$ and the HLH inhibitory transcription factors ID1, ID2, and ID4. We investigate the correlation between fibroblast growth factor signaling and supporting cell proliferation and show that FGF20 inhibits supporting cell proliferation. We also present an analysis of 212 differentially expressed transcription factor genes in the regenerative time course that fall into nine distinct gene expression patterns, many of which correlate with phenotypic events during regeneration and represent attractive candidates for future analysis and manipulation of the regenerative program in sensory epithelia and other vertebrate neuroepithelia.
\end{abstract}

Key words: hair cells; regeneration; RNA-seq; systems biology; utricle

\section{Introduction}

Loss of sensory hair cells is the major cause of hearing and balance disorders (Marazita et al., 1993; Blanchfield et al., 2001). Sensory hair cells reside in sensory epithelia that transduce sound and movement. In mammals, once these epithelia mature, they are incapable of sustained regeneration (Forge et al., 1993; Warchol et al., 1993); however, lower vertebrates have a robust regenerative capacity in their sensory epithelia (Corwin and Cotanche, 1988; Ryals and Rubel, 1988; Warchol and Corwin, 1996). Avian hair cell death triggers one of two outcomes in the surrounding supporting cells. They can either convert directly into new hair cells (Roberson et al., 2004; Duncan et al., 2006), a process called phenotypic conversion, or they can reenter the cell cycle and generate new hair cells and supporting cells by regenerative proliferation (Girod et al., 1989; Stone and Cotanche, 1994). Within the vertebrate ear, both the vestibular (balance) and the cochlea (auditory) systems rely on hair cells to transduce mechanical movements into electrical stimuli. The vestibular system is mor-

\footnotetext{
Received June 19, 2013; revised Dec. 31, 2013; accepted Jan. 7, 2014.

Author contributions: M.E.W. and M.L. designed research; Y.-C.K., R.V., and C.V. performed research; Y.-C.K., N.R., C.H., M.E.W., and M.L. analyzed data; Y.-C.K., M.E.W., and M.L. wrote the paper.

This work was supported by the National Institutes of Health (Grants RC1DC010677 to M.L. and R01DC006283 to

M.E.W. and National Institute on Deafness and Other Communication Disorders Grant P30DC04665).

The authors declare no competing financial interests.

Correspondence should be addressed to Professor Michael Lovett, NHLI, Imperial College, Guy Scadding Building,

Dovehouse Street, London SW3 6LY. E-mail: m.lovett@imperial.ac.uk.

DOI:10.1523/JNEUROSCI.2606-13.2014

Copyright $\odot 2014$ the authors $\quad 0270-6474 / 14 / 343523-13 \$ 15.00 / 0$
}

phologically conserved across diverse vertebrate species, whereas the mammalian auditory system has evolved specialized structures not present in other vertebrates (Meyers and Corwin, 2008).

Little is known about the genetic mechanisms that regulate regeneration in the sensory epithelia. One exception is the NOTCH pathway, which has been investigated in both mammals and birds during hair cell development and regeneration (Lindsell et al., 1996; Lanford et al., 1999; Stone and Rubel, 1999). Such studies demonstrated that the transcription factors $A T O H 1$ and various $H E S$ genes play important roles in determining hair cell and supporting cell fates via reciprocal inhibitory loops. Notably, the upstream regulators of these transcription factors and the downstream mechanisms that further specify a hair cell are largely unknown.

Our group conducted the first large-scale gene expression analysis of the regenerative process in the avian inner ear specifically focused upon changes in transcription factor gene expression (Hawkins et al., 2007). Here, we present the first comprehensive transcriptome, by RNA-Seq, of hair cell regeneration in the chick utricle across a $7 \mathrm{~d}$ time course from the first stages of response to damage through to the production of new hair cells by regenerative proliferation. We provide a considerable amount of pathway and pattern annotation and correlate the gene expression data with the proliferation of supporting cells, the production of new hair cells by phenotypic conversion, and the later production of hair cells by regenerative proliferation. We also describe the major discernible pat- 
terns and pathways, some of which are surprising and dynamic and show how these are a new discovery resource for accurately identifying components of the hair cell transcriptome. Finally, we investigate the correlation between fibroblast growth factor (FGF) signaling and the control of supporting cell proliferation and present a clustering analysis of gene expression changes for 212 differentially expressed transcription factors in the regenerative time course, the vast majority of which have never been studied in regeneration and represent attractive candidates for future analysis and manipulation of the regenerative program in many vertebrate systems.

\section{Materials and Methods}

Chick utricle cultures and isolation of sensory epithelia. Organotypic cultures of the chick utricle (extracted from both sexes) were prepared by previously described methods (Matsui et al., 2002). Utricles were treated with $1 \mathrm{~mm}$ streptomycin for $24 \mathrm{~h}$. Untreated cultures were maintained in parallel and served as matched controls. After $24 \mathrm{~h}$, all specimens were either harvested for analysis or were rinsed and maintained in culture for 1-7 d in streptomycin-free medium and fed at $2 \mathrm{~d}$ intervals. The pure sensory epithelia, consisting of only hair cells and supporting cells, were isolated from the underlying tissues either immediately after streptomycin treatment ( $0 \mathrm{~h}$ time point) or after $24-168 \mathrm{~h}$ of recovery in vitro. Utricles were rinsed and then incubated for $30 \mathrm{~min}$ in thermolysin (500 $\mu \mathrm{g} / \mathrm{ml}$ at $37^{\circ} \mathrm{C}$ ). Isolated epithelia for each time point and treatment group were pooled and dissolved in TRIzol reagent (Invitrogen). At least two biological samples (16 epithelia pooled from the streptomycintreated group and 16 from the control group) were collected for every time point.

Immunohistochemistry. Cultured utricles were fixed for $30 \mathrm{~min}$ with $4 \%$ paraformaldehyde, washed with PBS, incubated for $2 \mathrm{~h}$ in PBS with $5 \%$ normal horse serum, and incubated overnight in primary antibodies. Hair cells were labeled with antibodies against either otoferlin (HCS-1; a gift from Jeffrey Corwin University of Virginia, Charlottesville, VA) or Mysoin VIIa (1:500; Proteus). Antibodies for AP3B2, MDFI, and DNM1 were from Abcam. Specimens were rinsed with PBS and incubated for $2 \mathrm{~h}$ with secondary antibodies conjugated with fluorescent markers (Alexa Fluor 488 or 546; Invitrogen). Specimens were imaged with confocal microscopy (LSM 700; Zeiss) and processed with Volocity software (PerkinElmer).

Quantification of cell division and hair cell recovery. Proliferation was assessed at 1-7 d after aminoglycoside antibiotic treatment. Cultures received $\mathrm{BrdU}(3 \mu \mathrm{g} / \mathrm{ml})$ for the final $4 \mathrm{~h}$ in vitro. After fixation, utricles were processed for BrdU immunohistochemistry, an assay system that has been well described previously (Matsui et al., 2002), and imaged by confocal microscopy. BrdU-labeled cells were quantified from six $100 \times$ $100 \mu \mathrm{m}$ regions within the extrastriolar portion of each specimen. Data were obtained from 6-10 utricles per time point per treatment group. Hair cell recovery was quantified using similar methods. Regenerated hair cells were labeled with an antibody against myosin VIIa (see Immunohistochemistry, above). Confocal images were obtained and hair cells were quantified in six $100 \times 100 \mu \mathrm{m}$ extrastriolar regions per utricle.

FGF signaling and supporting cell proliferation. Cultured utricles were treated with either FGF20 (to activate FGFR1 and/or FGFR3) or SU5402 (to inhibit FGFRs). Utricles were treated for $24 \mathrm{~h}$ with $1 \mathrm{~mm}$ streptomycin, as described in Utricle culturing, above. Cultures were rinsed and given Medium-199 supplemented with 1\% FBS and containing either FGF20 ( $1 \mu \mathrm{g} / \mathrm{ml}$ with $1 \mu \mathrm{g} / \mathrm{ml}$ heparin sulfate; R\&D Systems) or SU5402 (30 $\mu \mathrm{M}$; Santa Cruz Biotechnology). Control cultures received either 1 $\mu \mathrm{g} / \mathrm{ml}$ heparin sulfate (FGF20 experiments) or 0.1\% DMSO (SU5402 experiments). Each treatment group contained 10-12 specimens. Utricles were incubated in media for $48 \mathrm{~h}$ and proliferation was measured as in Quantification of cell division, above. Statistical significance was assessed using Student's $t$ test.

RNA-Seq preparation. Samples from each time point were processed using Illumina mRNA-seq or TrueSeq preparation kits. In brief, mRNA was selected by oligo-dT magnetic beads from $1 \mu \mathrm{g}$ of total RNA and fragmented. First-strand cDNA was generated using random primers. Second-strand synthesis, end repair, addition of a single A base, and adaptor ligation were then performed. Each RNA-seq library was DNA sequenced using either the Illumina Genome Analyzer IIx or HiSeq 2000. In all cases, biological replicate samples from pure sensory epithelia were analyzed. The average correlation coefficient between biological replicates was 0.9423 . In some cases, we also ran technical replicates. The average correlation coefficient between technical replicates was 0.9979 .

RNA-Seq data analyses. Raw reads in FASTQ format were aligned to the Ensembl Gallus gallus reference genome (WUGSC2.1 E66) using Tophat v1.4.0 (Trapnell et al., 2009). The output.bam file was processed by Partek Genomics Suite version 6.6 to assemble reads into transcripts and estimate their abundances. A gene model dataset combining Ensembl and National Center for Biotechnology Information annotations was used to generate reads per kilobase of exon per million fragments mapped (RPKMs) for known genes and potential novel transcripts. Statistical significance levels were calculated by one-way ANOVA. Biological replicates had an average $R$ of $94 \%$. Reads mapped to different isoforms of a given gene were combined together for analysis. At least one sample across the entire time course was required to be $\geq 0.5 \mathrm{RPKM}$. At least one time point had to have a significant fold change $(p<0.05$ and fold change $\geq 1.8$ ). The same filters were applied to individual time points to produce a differentially expressed dataset. Gene lists from clustering analysis were uploaded to g:Profiler and analyzed by gene group functional profiling. Pathways that were predicted from g:Profilers database of literature-supported interaction datasets were visualized by Cytoscape. All sequence data and annotations have been submitted to NCBI Gene Expression Omnibus (GEO) and are available online.

Quantitative real-time PCR. Total RNA was isolated from a time course of treated and control chicken sensory epithelia at all time points and was converted to cDNA. Quantitative real-time PCR (qRT-PCR) was performed using the ABI TaqMan Gene Expression Master Mix (Applied Biosystems) on an ABI 7900HT real-time PCR machine. All of the qRT-PCR assays were obtained from Integrated DNA Technologies and were run in triplicate. The expression of $18 \mathrm{~S}$ rRNA was used as a normalization control. Twenty genes (including ATOH1 and HES5) were selected for validation across every time point (in triplicate) across a new parallel set of biological samples (a total of 660 qRT-PCR assays). The average correlation between the fold change in qRT-PCR and RNAseq was $86 \%$ and in all cases the trends agreed.

\section{Results}

We used an in vitro organotypic culture system in which hair cell regeneration is similar to that observed in vivo (Warchol, 1999, Matsui et al., 2002). Whole utricles were placed in culture and subjected to $24 \mathrm{~h}$ of aminoglycoside antibiotic treatment, which kills $\sim 93 \%$ of the hair cell population (Warchol and Montcouquiol, 2010). Untreated utricles were cultured in parallel and served as controls. After aminoglycoside antibiotic treatment, the sensory epithelia of some specimens (along with untreated controls) were removed for RNA-Seq; this is the zero time point (see Materials and Methods). Other specimens were rinsed and cultured for 1-7 d. We sampled at $24 \mathrm{~h}$ intervals up to $168 \mathrm{~h}$. All of our RNA-Seq data were derived from pure sensory epithelia without any detectable stromal contamination. These sensory epithelia consist of hair cells and supporting cells, the latter of which act as progenitors for hair cell regeneration. The ratio of supporting cells to hair cells is $\sim 4: 1$ (Goodyear et al., 1999). The initial hair cell density in these cultures is $\sim 180 / 10,000 \mu \mathrm{m}^{2}$ and drops to $\sim 12 / 10,000 \mu \mathrm{m}^{2}$ after antibiotic treatment. Large numbers of the supporting cells undergo proliferation within $96 \mathrm{~h}$ after antibiotic treatment, resulting in the eventual replenishment of hair cell numbers. In addition, a minority of new hair cells are produced by direct phenotypic conversion within the first 2-3 d after antibiotic injury. It became clear from our initial samples that surprising changes in gene expression were occurring in the $48-72 \mathrm{~h}$ window of regeneration. We therefore sampled at $6 \mathrm{~h}$ intervals across the $48-72 \mathrm{~h}$ window $(56,60$, and $66 \mathrm{~h})$. 

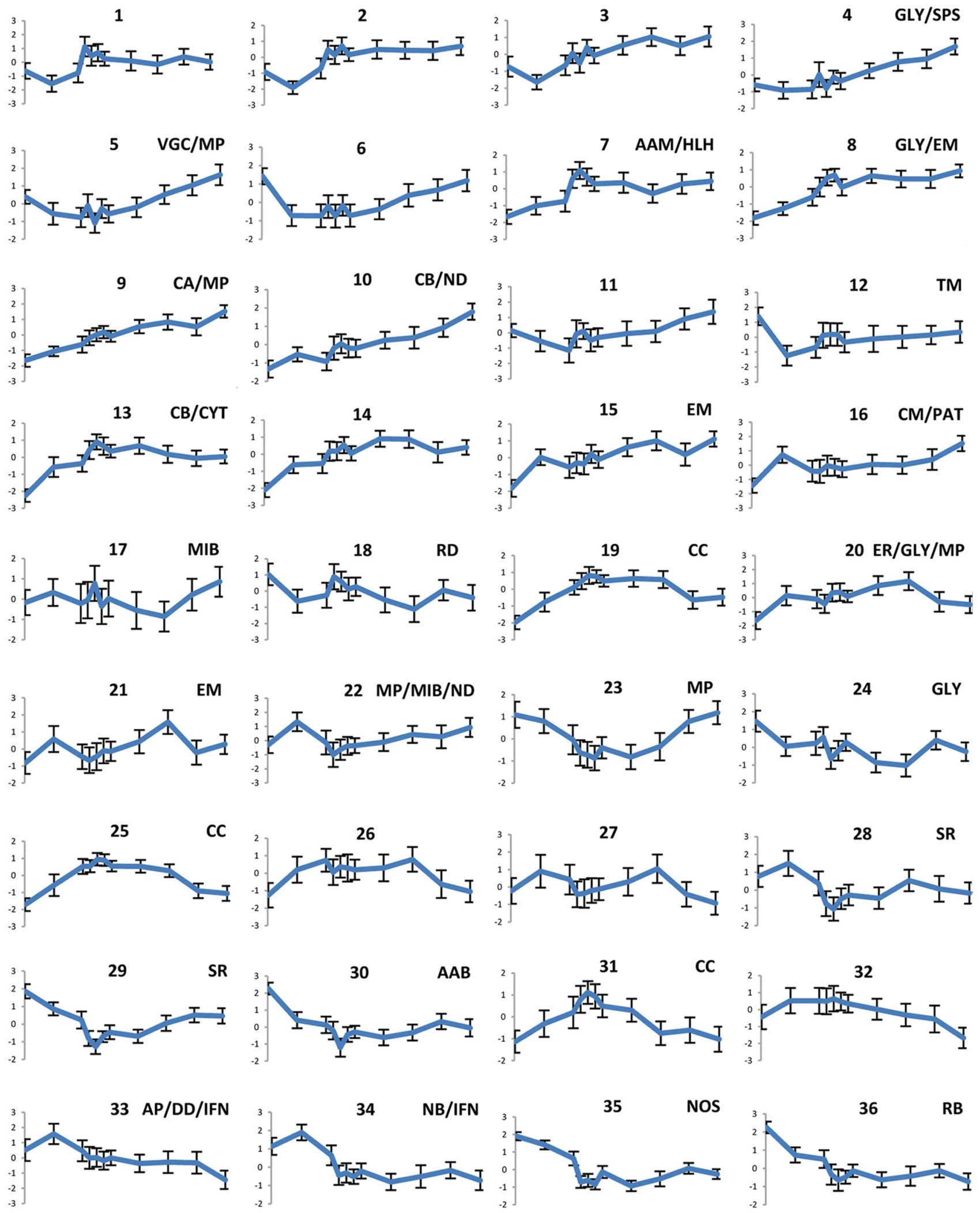

Figure 1. Differentially expressed gene clusters analyzed by SOMs. Differentially expressed genes were clustered into 36 centroids by SOMs (Partek). Each $x$-axis indicates individual time points. The $y$-axis shows the average normalized fold change $\left(\log _{2}\right)$ for all the genes in the centroid, with the bars showing the range. The number within each centroid refers to a gene cluster referred to in the text. The specific number of genes and gene IDs in each cluster are listed in supplemental Table 4. Some of the correlations between DAVID functional annotations and patterns are shown within each centroid, with the following codes: $A A B$, amino acid biosynthesis; $A A M$, amino acid metabolism; $A P$, apoptosis; $C A$, channel activity; $C B$, calcium binding; $C C$, cell cycle; $C M$, cell migration; CYT, cytoskeleton; DD, DNA damage; EM, extracellular matrix; ER, endoplasmic reticulum; GLY, glycosylation; HLH, helix loop helix genes; IFN, interferon responses; MIB, metal ion binding; MP, membrane proteins; NB, nucleolus biosynthesis; ND, neural development; NOS, nuclear organelle synthesis; PAT, patterning; RB, RNA binding; RD, regulation of differentiation; SPS, sensory perception of sound; SR, stress response; TM, transmembrane transport; and VGC, voltage gated channels. 
In all cases, at least two biological replicates were analyzed at every time point. The Materials and Methods section include information on data reproducibility. We conducted qRT-PCR on RNA samples from a separate time course across all 11 time points on 20 genes to validate the mRNA-Seq data. In all cases, these trends agreed (data are available online).

\section{Defining the regenerative transcriptome}

We set our threshold for differentially expressed genes at $\geq 1$.8fold and a $p$-value $<0.05$ at any one time point for treated versus control cultures. Raw sequences have been submitted to NCBI GEO (accession number applied for) and all annotations are available online. We also required that the abundance level of each transcript was $\geq 0.5$ RPKM (Mortazavi et al., 2008) in any sample. This resulted in a list of 3661 genes differentially expressed at any single time point.

\section{Correlations between expression patterns and functional annotations}

Lists of upregulated and downregulated genes at individual time points were uploaded to the DAVID Bioinformatics Resource 6.7 (da Huang et al., 2009) to perform gene ontology (GO) enrichment analysis (data are available online in supplemental Table 9). At early time points (unsurprisingly), sensory perception of sound processes are depleted $\left(\sim 10 \%\right.$ of genes with $p$-values $\left.<10^{-5}\right)$, reflecting the death of hair cells. For upregulated genes, the GO terms are enriched for cell cycle annotations from 24 to $120 \mathrm{~h}$ ( 20\% of genes and $p$-values $<10^{-5}$ ). This switch in cell cycle (on at $24 \mathrm{~h}$ and off at $120 \mathrm{~h}$ ) agrees with studies that observed mitotically regenerated hair cells $\sim 6 \mathrm{~d}$ after aminoglycoside antibiotic treatment (Cotanche et al., 1994). After $120 \mathrm{~h}$, the number of differentially expressed genes decreases by $52 \%$, reflecting the cessation of the proliferative program. At these later stages, GO annotations point to switches in extracellular matrix production and glycoproteins. This coincides with the period when mature hair cells develop from regenerative proliferation of the supporting cells.

To identify more specific patterns, we clustered all differentially expressed genes by unsupervised clustering within selforganizing maps (SOMs; Kohonen, 1982) to identify 36 patterns across the time course (Fig. 1). This number of distinct patterns was arrived at empirically by deriving smaller ( 20 centroids) and increasingly larger numbers of unsupervised clusters. It is a compromise between deriving duplicate patterns (e.g., cell cycle patterns) and observing discrete interesting patterns that are enriched for different cellular processes. For example, centroids 19, 25, and 31 in Figure 1 are highly enriched for cell cycle programs, indicating that this initiates at $24 \mathrm{~h}$ and has largely ceased by $120 \mathrm{~h}$. We also conducted functional annotations and network analyses on these SOM clusters using the DAVID, g:Profiler (Reimand et al., 2011), and Cytoscape tools (Smoot et al., 2011). Several of these functional correlations are shown in Figure 1.

\section{Correlating the time course with regenerative phenotypes}

Studies of hair cell regeneration have generally used two phenotypic measurements: (1) supporting cell proliferation measured by incorporation of BrdU into DNA (Gratzner, 1982) and (2) the production of mature hair cells measured by the presence of haircell-specific proteins such as myosin VIIA (Avraham et al., 1995). We quantified these across the regenerative time course. Figure 2 shows the proliferation index and hair cell recovery values. DNA replication (Fig. $2 A$ ) is a highly punctuated process, with a peak at $48 \mathrm{~h}$ followed by a steep decline. This peak contrasts with the spectrum of cell-cycle-related transcripts (Fig. 1, top), which
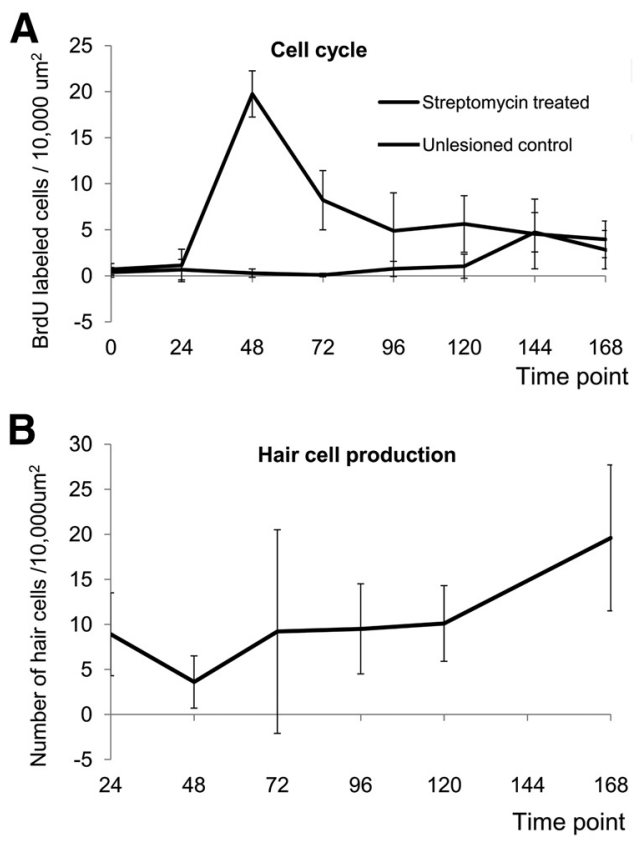

Figure 2. Phenotypic measurements across the regenerative time course. $A$, DNA replication in supporting cells was measured by a BrdU incorporation assay. The $x$-axis indicates individual time points. The $y$-axis shows the mean number of BrdU-labeled cells per $10,000 \mu \mathrm{m}^{2} \pm$ SD in control and streptomycin-treated organotypic cultures. $\boldsymbol{B}$, The number of mature hair cells was quantified by measuring MY07a-labeled cells. Chicken utricle sensory epithelia organotypic cultures were treated with streptomycin and immunohistochemically labeled for MY07a to detect mature hair cells. The $x$-axis indicates individual time points. The $y$-axis shows the mean number of hair cells per $10,000 \mu \mathrm{m}^{2} \pm$ SD.

number $>300$ different GO-annotated gene products and collectively show a long plateau of expression. These transcripts only decline in expression as a group at $96-120 \mathrm{~h}$, presumably because the replication machinery is used to ensure complete cytokinesis.

Measuring the appearance of new hair cells by MYO7a staining is complicated by the persistence of dead (but unextruded) hair cells within the injured sensory epithelia. There is nevertheless evidence from MYO7a staining (Fig. 2B) that hair cell numbers decline through the $48 \mathrm{~h}$ time point and are then replenished by $72 \mathrm{~h}$ (consistent with a period of phenotypic conversion in that time frame), followed by an $\sim 2$-fold increase by $168 \mathrm{~h}$ (from regenerative proliferation).

\section{Identifying components of the hair cell transcriptome}

A more refined measure of hair cell production is provided by tracking a panel of 32 genes that are known to mark hair cells within the utricle sensory epithelia (these include $M Y O 7 a$ ) in the RNA-Seq data shown in Figure 3. All of these showed a $>2$-fold drop (range of -2-fold to -16-fold) in gene expression after aminoglycoside antibiotic treatment, reflecting hair cell loss, and then showed various patterns of recovery, with all showing higher expression levels at $168 \mathrm{~h}$. Interestingly, many of them exhibited either a peak or plateau of expression at $\sim 72 \mathrm{~h}$, coincident with the probable onset of phenotypic conversion and the production of a minority of new hair cells. The majority of these markers do not return to wild-type levels by $168 \mathrm{~h}$, which is consistent with the replenishment of $\sim 25 \%$ of normal hair cell numbers by this time.

We used this pattern as a filter to identify new hair-cellspecific markers. Defining the hair cell transcriptome remains a challenge. At present, only a small proportion of the hair cell transcriptome has been identified. For example, various array- 


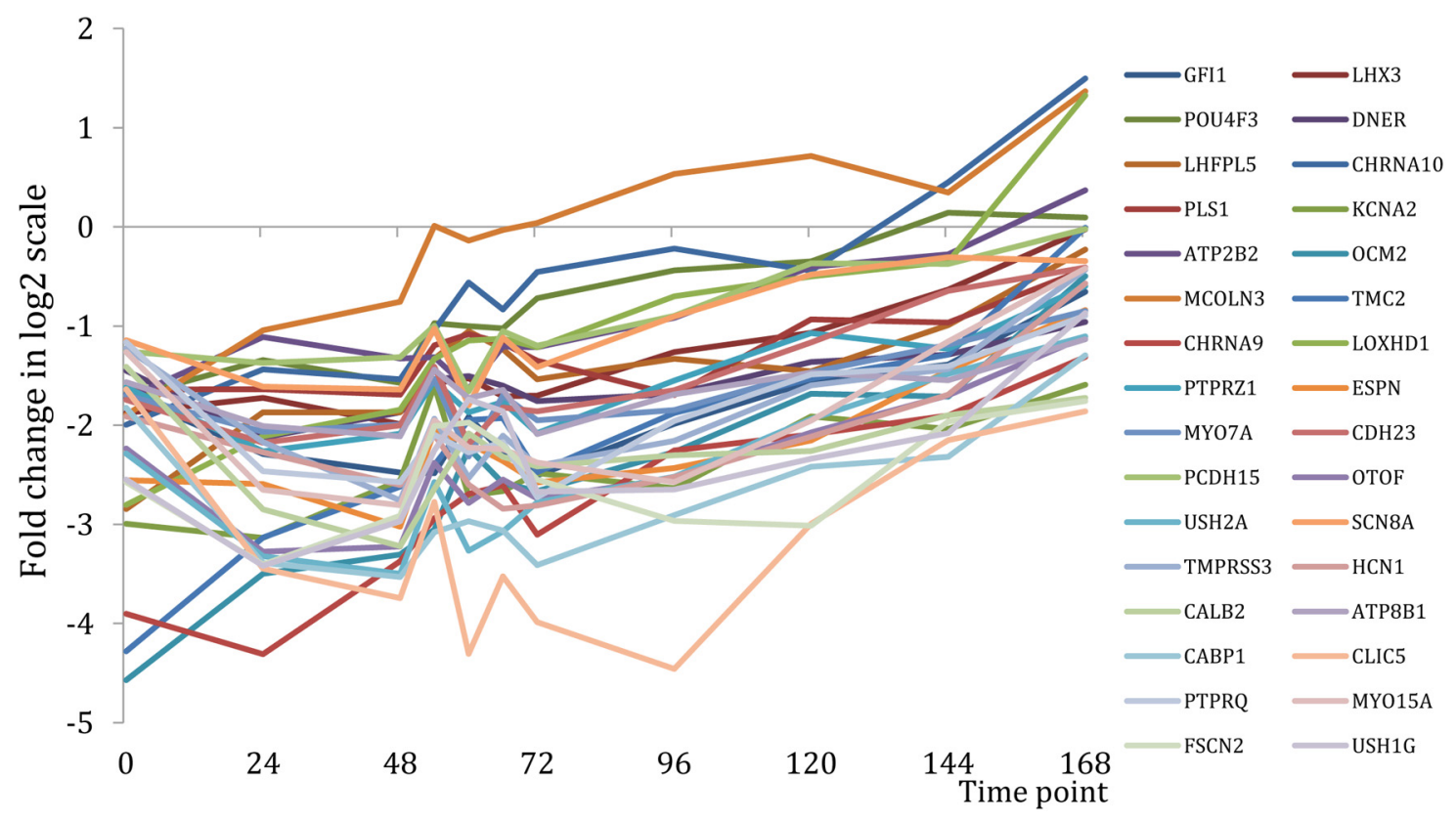

Figure 3. Expression profiles of 32 known hair cell markers. The $x$-axis indicates individual time points. The $y$-axis shows the fold change of streptomycin-treated versus control samples on a log 2 scale. These sentinel genes are significantly downregulated at the 0 and $24 \mathrm{~h}$ time points and showed a recovery trend toward the end of the time course.

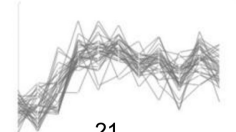

21
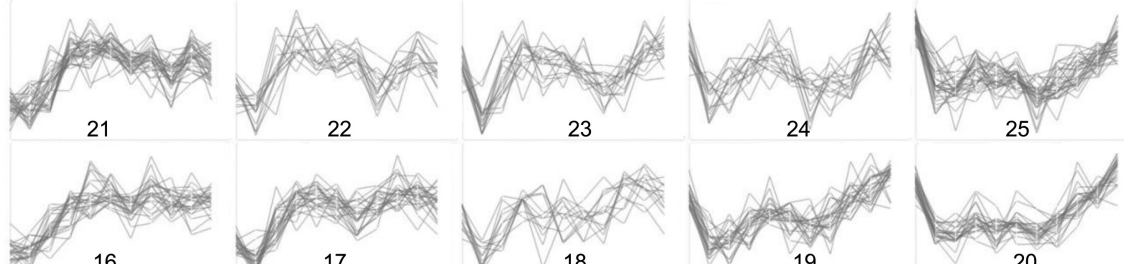

16
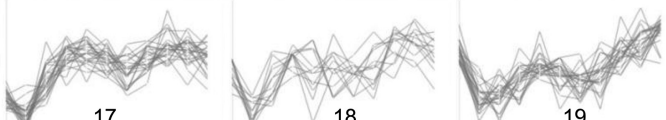

19
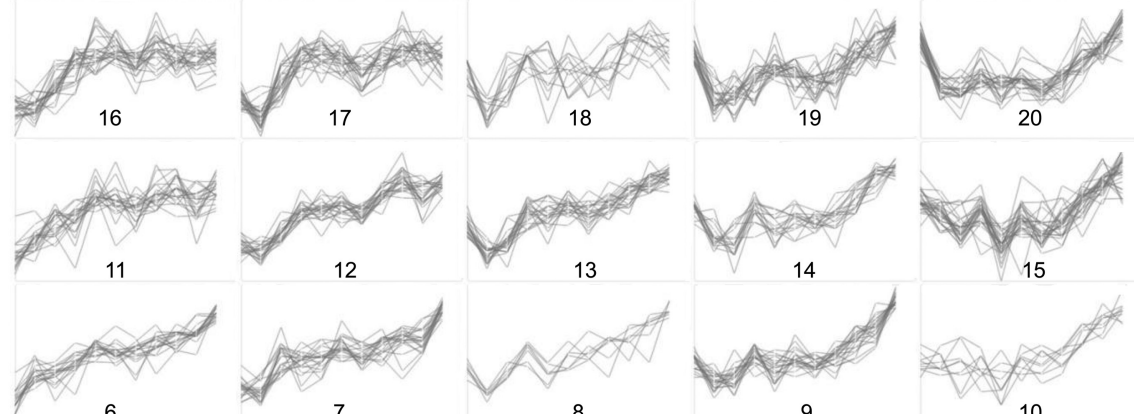

7

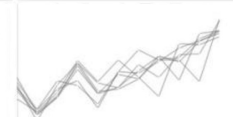

8

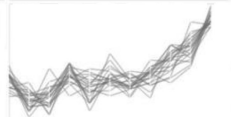

9
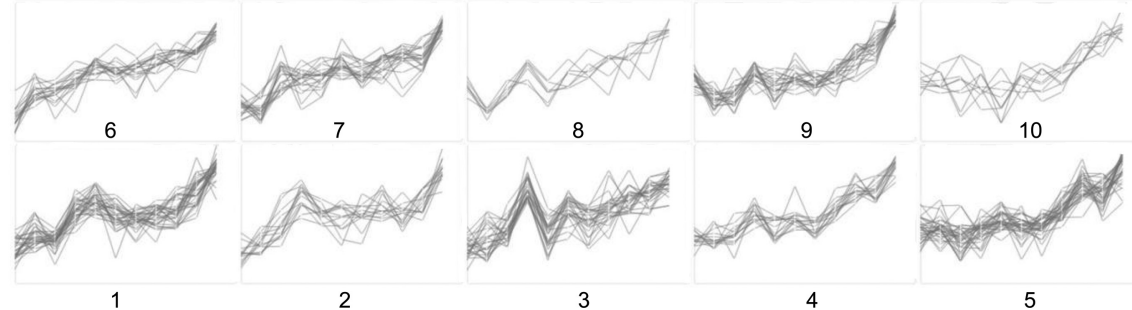

2

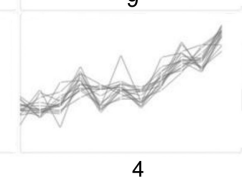

3

Figure 4. SOMs of potential hair cell markers. Genes that passed the filters for potential hair cell markers (downregulated $>2$-fold at $0-24 \mathrm{~h}$ and a recovery trend by the $168 \mathrm{~h}$ time point) were clustered into 25 groups by $50 M$ (Partek). The $x$-axis of each group indicates individual time points. The $y$-axis shows the normalized fold change.

based methods (McDermott et al., 2007; Hertzano et al., 2011; Sinkkonen et al., 2011) and proteomic studies (Herget et al., 2013; Shin et al., 2013) have identified a few hundred hair cell markers. Therefore, we implemented a filter on the entire list of 3661 genes that required a $>2$-fold expression drop at $0-24$ $\mathrm{h}$ and a relative recovery by $168 \mathrm{~h}$. This resulted in a list of 526 genes (some examples are shown in Table 1), within which were our 32 hair cell "sentinel" genes. We then derived 25 SOM clusters from this set (Fig. 4). All of these clusters showed the same trends at the beginning and end of the time course, but there were reproducible fluctuations at $48-72 \mathrm{~h}$, which is consistent with phenotypic conversion of supporting cells to hair cells. This interpretation is supported by previous studies

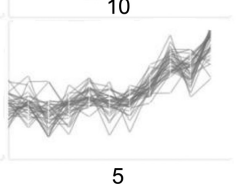

5 showing that phenotypic conversion occurs at $\sim 3 \mathrm{~d}$ after antibiotic removal (Roberson et al., 2004) and by our measurements of MYO7a protein.

To determine whether our filtered set was indeed enriched for bona fide haircell-specific genes, we chose three with available antibodies for validation by immunohistochemistry. The first of these, DNM1, encodes a member of the dynamin subfamily of GTP-binding proteins. It has been implicated in signal transduction and vesicle trafficking (Sever, 2002; Wiejak and Wyroba, 2002). DNM1 colocalized with $M Y O 7 a$ within all hair cells (Fig. $5 A$ ), suggesting that it may be a part of the stereocilia bundle. The second gene, $A P 3 B 2$, encodes a subunit of the adapter protein complex 3 and plays a role in neurotransmitter release (Newman et al., 1995; Faúndez et al., 1998). AP3B2 was specifically expressed in the hair cell cytoplasm (Fig. 5B) and at similar levels across all hair cells. The third gene was MDFI, which encodes a MyoD family inhibitor. This transcription factor negatively regulates other myogenic family proteins, interacts with Axin, and regulates the JNK and WNT pathways (Kusano and Raab-Traub, 2002). Approximately $90 \%$ of utricle hair cells were labeled for MDFI (Fig. 5 C), but the intensity of nuclear staining varied, with $\sim 33 \%$ being intensely stained.

We conclude that the 494 filtered genes are enriched for new hair cell markers. Furthermore, in addition to MDFI, an additional 13 transcription factor genes are present in our putative hair cell clusters. These are noteworthy because so few hair-cellspecific transcription factors have been previously described. Of the 14 transcription factor genes listed in Table 2, three are 
Table 1. Examples of putative hair-cell-specific genes identified in this study

\begin{tabular}{|c|c|}
\hline Gene & Description \\
\hline$B S N$ & Bassoon (presynaptic cytomatrix protein) \\
\hline CAB39L & Calcium binding protein 39-like \\
\hline CACNATB & Calcium channel, voltage-dependent, $\mathrm{N}$ type, alpha $1 \mathrm{~B}$ subunit \\
\hline CADM2 & Cell adhesion molecule 2 \\
\hline CAPSL & Calcyphosine-like \\
\hline CASQ2 & Calsequestrin 2 (cardiac muscle) \\
\hline GPR143 & G protein-coupled receptor 143 \\
\hline GPR149 & G protein-coupled receptor 149 \\
\hline GPR98 & G protein-coupled receptor 98 \\
\hline KCNA1 & Potassium voltage-gated channel, shaker-related subfamily, member 1 \\
\hline KCNA3 & Potassium voltage-gated channel, shaker-related subfamily, member 3 \\
\hline KCNA4 & Potassium voltage-gated channel, shaker-related subfamily, member 4 \\
\hline KCNAB1 & Potassium voltage-gated channel, shaker-related subfamily, beta member 1 \\
\hline KCNAB2 & Potassium voltage-gated channel, shaker-related subfamily, beta member 2 \\
\hline KCNH6 & Potassium voltage-gated channel, subfamily H (eag-related), member 6 \\
\hline KCNJ2 & Potassium inwardly-rectifying channel, subfamily J, member 2 \\
\hline KCNS2 & Potassium voltage-gated channel, delayed-rectifier, subfamily $S$, member 2 \\
\hline KCNU1 & Potassium channel, subfamily U, member 1 \\
\hline MYBPC1 & Myosin binding protein C, slow type \\
\hline MYH7B & Myosin, heavy chain 7B, cardiac muscle, beta \\
\hline MYLK4 & Myosin light chain kinase family, member 4 \\
\hline MY018B & Myosin XVIIIB \\
\hline MYO1H & Myosin IH \\
\hline MY03A & Myosin IIIA \\
\hline MYO3B & Myosin IIIB \\
\hline PCDH2O & Protocadherin 20 \\
\hline PCDH8 & Protocadherin 8 \\
\hline PCDH9 & Protocadherin 9 \\
\hline PCLO & Piccolo (presynaptic cytomatrix protein) \\
\hline PCP4 & Purkinje cell protein 4 \\
\hline SLITRK4 & SLIT and NTRK-like family, member 4 \\
\hline SMPX & Small muscle protein, $X$-linked \\
\hline SNTN & Sentan, cilia apical structure protein \\
\hline SPHKAP & SPHK1 interactor, AKAP domain containing \\
\hline SPINK4 & Serine peptidase inhibitor, Kazal type 4 \\
\hline SPOCK3 & Sparc/osteonectin, cwcv and kazal-like domains proteoglycan \\
\hline SPRY3 & Sprouty homolog 3 (Drosophila) \\
\hline$S V 2 B$ & Synaptic vesicle glycoprotein $2 B$ \\
\hline SYN3 & Synapsin III \\
\hline SYNC & Syncoilin, intermediate filament protein \\
\hline SYT10 & Synaptotagmin X \\
\hline TESC & Tescalcin \\
\hline TM4SF18 & Transmembrane $4 \mathrm{~L}$ six family member 18 \\
\hline$T M C 5$ & Transmembrane channel-like 5 \\
\hline TMCC2 & Transmembrane and coiled-coil domain family 2 \\
\hline TMEM117 & Transmembrane protein 117 \\
\hline TMEM151B & Transmembrane protein 151B \\
\hline TMIGD1 & Transmembrane and immunoglobulin domain containing 1 \\
\hline TMPRSS7 & Transmembrane protease, serine 7 \\
\hline TMPRSS9 & Transmembrane protease, serine 9 \\
\hline
\end{tabular}

Fifty examples of putative new hair-cell-specific markers are listed from the overall list of 494 genes (available online) identified by our pattern and cluster analysis.

known hair-cell-specific transcription factors (POU4F3, GFI1 and $L H X 3$ ), one is the MDFI gene we validated, and the remaining 10 are new candidates for further investigation of hair cell gene regulation. It is worth noting that our new putative hair cell markers, unsurprisingly, have little overlap with the few hundred described in the various array-based and proteomic-based studies cited above.

Network analysis of the entire 526 putative hair-cell-specific genes provides independent evidence for a proportion of them interacting. Figure 6 shows one part of this overall g:Profiler (Reimand et al., 2011)-predicted hair cell network in which 94 of the detectable genes in the regenerative transcriptome are linked
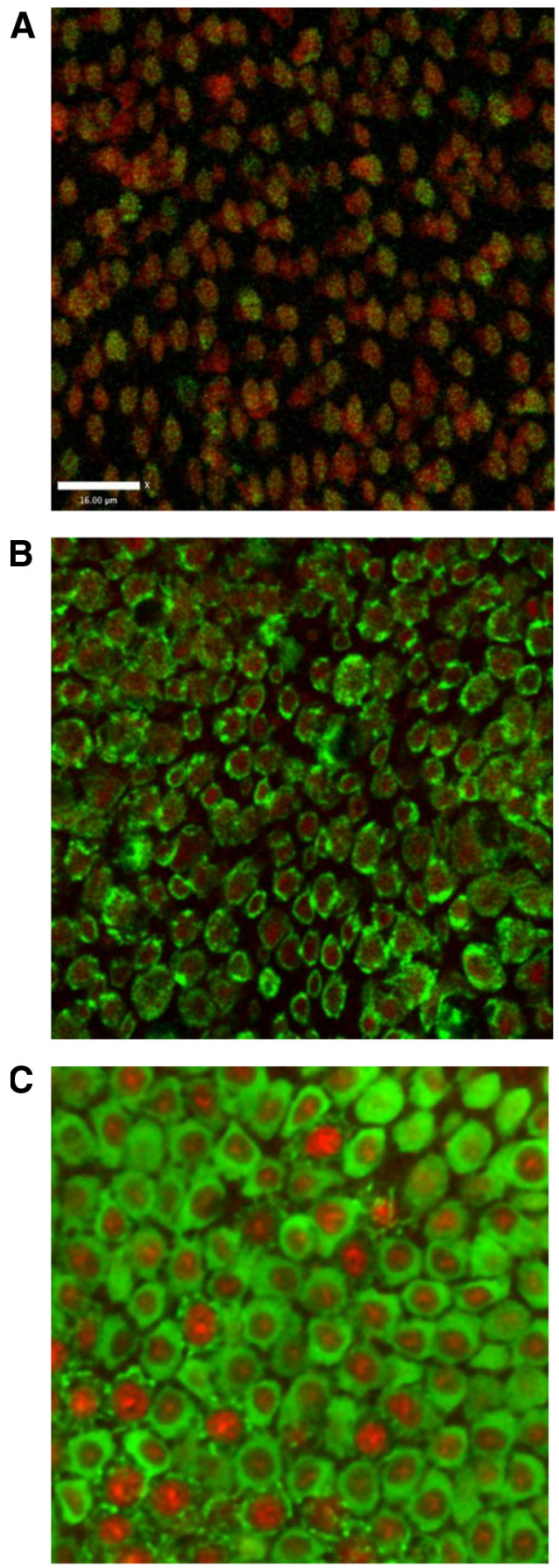

Figure 5. Immunohistochemical staining of novel hair cell markers. Chicken utricles were labeled with antibodies to known hair markers (MY07a or otoferlin) and to potential novel hair cell markers identified in the present study. Scale bar, $16 \mu \mathrm{m}$. A, DNM1 (green) and MYO7a (red) are colocalized within all hair cells and are expressed at similar levels. $\boldsymbol{B}$, Hair cells are labeled for otoferlin (green). AP3B2 (red) is expressed homogeneously within the cytoplasm of hair cells. $C$, MY07a (green) labels hair cells and MDFI (red) labels the nuclei of a subpopulation of hair cells at various intensity levels. The images show the apical surface of the sensory epithelium with supporting cells filling the gaps between the labeled hair cells.

within a network (supported by literature citations to be found within the g:Profiler database) that includes one known hair cell marker (KCNA2), one of our new validated markers (DNM1), and 13 of our putative new hair-cell-specific markers. Therefore, in other cell systems there is independent evidence that these gene products directly interact. 
Table 2. Examples of significant transcription factor gene clusters

\begin{tabular}{|c|c|}
\hline Description & Gene \\
\hline \multicolumn{2}{|l|}{ Hair-cell-specific transcription factors } \\
\hline Ankyrin repeat domain 5 & ANKRD5 \\
\hline D4, zinc and double PHD fingers, family 3 & DPF3 \\
\hline Dorsal root ganglia homeobox & DRGX \\
\hline Forkhead box F1 & FOXF1 \\
\hline Growth factor independent 1 transcription repressor & $G F / 1^{a}$ \\
\hline Iroquois homeobox 2 & $\operatorname{lR} X 2$ \\
\hline LIM homeobox 3 & $\operatorname{LHX} 3^{a}$ \\
\hline Myod family inhibitor & $M D F I^{b}$ \\
\hline MLX interacting protein-like & MLXIPL \\
\hline Nuclear factor of activated T-cells, cytoplasmic, calcineurin-dependent 1 & NFATC1 \\
\hline Brain-specific homeobox/POU domain protein 3 & POU4F $3^{a}$ \\
\hline SKI family transcriptional corepressor 1 & SKOR1 \\
\hline SKI family transcriptional corepressor 2 & SKOR2 \\
\hline Zinc finger protein $385 \mathrm{~B}$ & ZNF385B \\
\hline \multicolumn{2}{|l|}{ Transcription factor gene expression clusters } \\
\hline \multicolumn{2}{|l|}{$\begin{array}{l}\text { Dip at } 54 \text { hours ( } 18 \text { genes) coincident with phenotypic conversion } \\
\text { (centroid number }=7 \text { ) }\end{array}$} \\
\hline B-cell translocation gene 1, anti-proliferative & BTG1 \\
\hline $\begin{array}{l}\text { Cbp/p300-interacting transactivator, with Glu/Asp-rich carboxy- } \\
\text { terminal domain, } 4\end{array}$ & CITED4 \\
\hline Hairy and enhancer of split 5 & HES5 \\
\hline Hairy and enhancer of split 7 & HEST \\
\hline Interferon regulatory factor 4 & IRF4 \\
\hline Hairy and enhancer of split 5-like & LOC419390 \\
\hline Myod family inhibitor & MDFI \\
\hline PR domain containing 5 & PRDM5 \\
\hline Prickle homolog 1 & PRICKLE1 \\
\hline Prickle homolog 2 & PRICKLE2 \\
\hline Synovial sarcoma translocation gene on chromosome 18 -like 1 & SS18L1 \\
\hline Storkhead box 1 & STOX1 \\
\hline Tripartite motif containing 24 & TRIM24 \\
\hline Teashirt zinc finger homeobox 1 & TSHZ1 \\
\hline Zinc finger, matrin-type 4 & ZMAT4 \\
\hline Zinc finger protein 385B & ZNF385B \\
\hline Zinc finger protein 395 & ZNF395 \\
\hline Zinc finger protein $804 \mathrm{~A}$ & ZNF804A \\
\hline \multicolumn{2}{|l|}{$\begin{array}{l}\text { Dip at } 120 \text { hours }(25 \text { genes) coincident with cell cycle cessation (centroid } \\
\text { number }=13 \text { ) }\end{array}$} \\
\hline AT rich interactive domain 5 A (MRF1-like) & ARID5A \\
\hline Camp responsive element modulator & CREM \\
\hline Histone deacetylase 7 & HDAC7 \\
\hline Inhibitor of DNA binding 2, dominant negative helix-loop-helix protein & 102 \\
\hline Notch 1 & NOTCH1 \\
\hline Nuclear receptor subfamily 4, group A, member 3 & NR4A3 \\
\hline Peroxisome proliferator-activated receptor delta & PPARD \\
\hline $\begin{array}{l}\text { Serum response factor (c-fos serum response element-binding } \\
\text { transcription factor) }\end{array}$ & SRF \\
\hline Tripartite motif containing 45 & TRIM45 \\
\hline Zinc finger protein 503 & ZNF503 \\
\hline Zinc finger protein 541 & ZNF541 \\
\hline Atonal homolog 1 & ATOH1 \\
\hline Distal-less homeobox 5 & DLX5 \\
\hline Distal-less homeobox 6 & $D L X 6$ \\
\hline Ets homologous factor & $E H F$ \\
\hline E74-like factor 3 (ets domain transcription factor, epithelial-specific) & ELF3 \\
\hline Forkhead box J1 & F0XJ1 \\
\hline Hematopoietic cell-specific Lyn substrate 1 & HSLS1 \\
\hline Hairy and enhancer of split 6 & HES6 \\
\hline Hairy/enhancer-of-split related with YRPW motif-like & HEYL \\
\hline Inhibitor of DNA binding 1, dominant negative helix-loop-helix protein & ID1 \\
\hline Inhibitor of DNA binding 4, dominant negative helix-loop-helix protein & ID4 \\
\hline MLX interacting protein-like & MLXIPL \\
\hline
\end{tabular}

Table 2. Continued

\begin{tabular}{cl}
\hline Description & Gene \\
\hline $\begin{array}{c}\text { SWI/SNF related, matrix associated, actin dependent regulator of } \\
\text { chromatin, subfamily c, member } 1\end{array}$ & SMARCC1 \\
Zinc finger, MYND-type containing 10 & \\
Peaks at $54-72$ hours (8 genes) coincident with phenotypic conversion & ZMYND10 \\
$\quad$ (centroid number = 16) & \\
Ankyrin repeat domain 33 & ANKRD33 \\
Four and a half LIM domains 2 & FHL2 \\
Forkhead box F1 & FOXF1 \\
Iroquois homeobox 2 & IRX2 \\
LIM domain only 3 (rhombotin-like 2) & LM03 \\
Mastermind-like domain containing 1 & MAMLD1 \\
Recombination signal binding protein for immunoglobulin kappa J & RBPJL \\
region-like & \\
Vitamin D (1,25-dihydroxyvitamin D3) receptor & VDR \\
\hline
\end{tabular}

There are 14 transcription factor genes that are potential new hair cell markers by clustering analysis. A list of transcription factor genes that correlate with three of the patterns of gene expression are shown in Figure 8. All gene lists and centroid numbers are available online.

${ }^{a}$ Known hair cell markers.

${ }^{b}$ Validated in this study (see Fig. 5).

\section{Components of known pathways and processes within the} differentially expressed genes

We next extracted components of known and interesting signaling pathways/gene families from the overall dataset. We extracted data for 47 pathways/gene families that have been implicated in hair cell development or regeneration (data are available online). Here, as examples of the rich information content in these data, we highlight observations on just two of these pathways that play key roles in sensory epithelia biology: NOTCH (Lanford et al., 1999; Stone and Rubel, 1999) and FGF (Alvarez et al., 2003) signaling.

\section{NOTCH pathway}

Our data include significant alterations in the expression of 25 components of NOTCH signaling. One of these is ATOH1. Elevated levels of $A T O H 1$ are associated with hair cell differentiation and initiate a process of lateral inhibition in which $A T O H 1$ represses HES genes. Elevated ATOH1 also leads to enhanced levels of Delta and Jagged. These bind to NOTCH receptors on adjoining cells. Processing of NOTCH then leads to the expression of various HES transcription factor genes that repress ATOH1 expression within these neighboring cells and direct them toward a supporting cell fate (Morrison et al., 1999; Zine et al., 2001). Previous studies have suggested that the major HES paralogs downstream of NOTCH signaling in the utricle are HES1 and HES5 (Heitzler et al., 1996; Lanford et al., 2000). HES1 does not show significant changes in gene expression in our dataset, although it is detectably expressed. However, HES5 is abundantly expressed and dynamically regulated during avian utricle regeneration. Notably, the expression of HES5 was sharply reduced immediately after ototoxic injury. This observation, combined with high levels of NOTCH expression, suggests that $\mathrm{NOTCH}$ signaling is tonically active in the normal utricle and that this is interrupted by hair cell death. We also noted a dip in HES5 expression in the $24-72 \mathrm{~h}$ interval in our original time course (Fig. $7 A)$. Therefore, we investigated this in more detail at $6 \mathrm{~h}$ intervals (54, 60, and 66 h; Fig. 7B). HES5 expression dramatically increases across the time course and appears to do so in an oscillatory manner. Some HES genes are known to act within natural oscillatory networks (Bessho et al., 2001; Hirata et al., 2002). HES5 expression appears to drop within the $48-72 \mathrm{~h}$ interval. This corresponds to the time frame for phenotypic conversion 

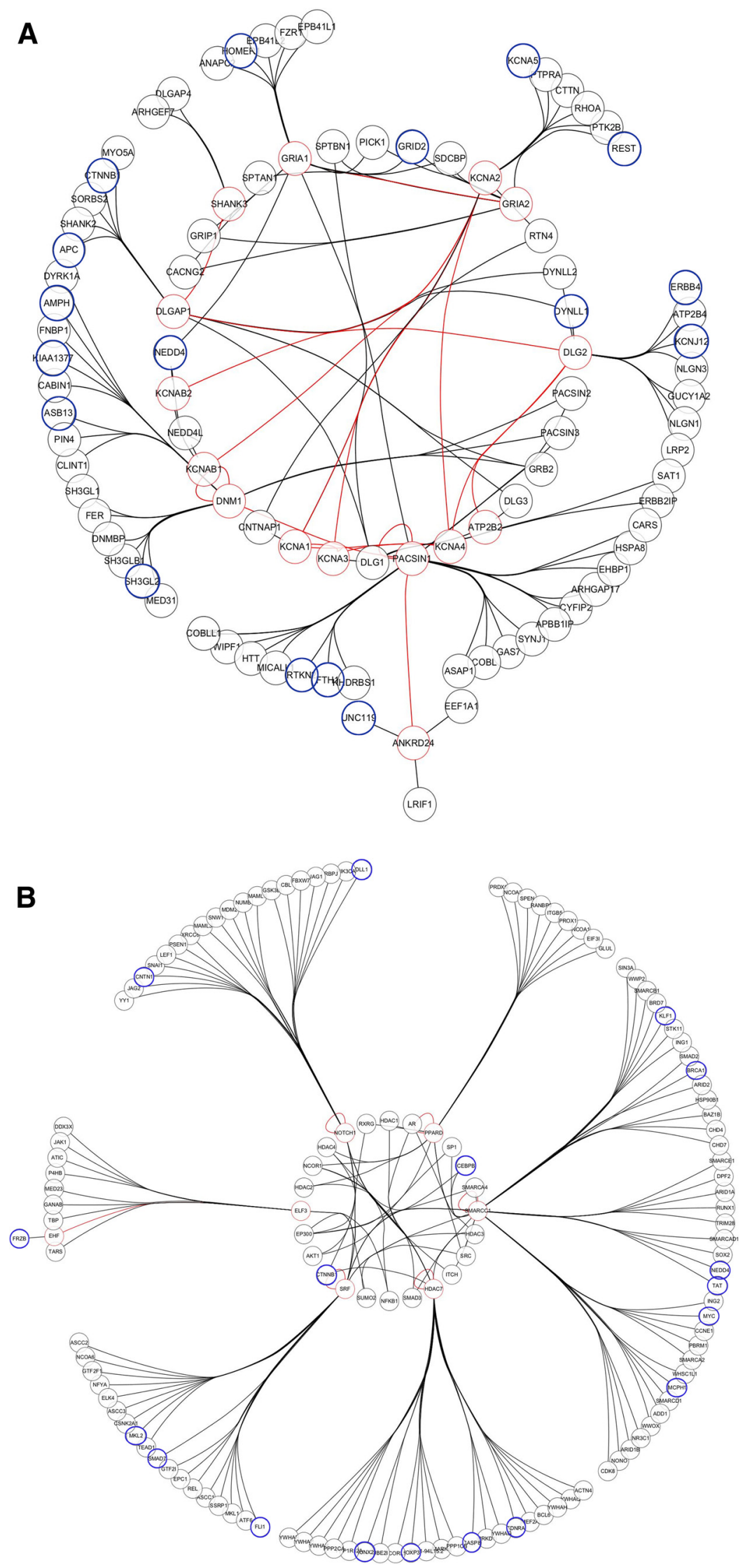

Figure 6. Examples of gene networks within the clustered data. $\boldsymbol{A}$, Network of interactions between putative hair-cell-specific genes. All 526 hair-cell-specific gene names from the clustering analysis were uploaded to g:Profiler and analyzed as described in the Materials and Methods. This figure includes only genes detectably expressed in the regenerative time course. Red circles denote genes within the 526 putative hair-cell-specific input set. Red lines indicate interactions between those genes/gene products. and correlates well with the intermediate peaks in hair cell marker expression. A surprising observation is the closely parallel pattern of gene expression exhibited by the HES7 gene (Fig. 7B). This gene plays a key oscillatory role in somitogenesis (Niwa et al., 2011), but has never been investigated or implicated in inner ear development. It is expressed at an $\sim 10$-fold lower level than HES5 in our dataset, but it also exhibits a parallel dip in expression at $54 \mathrm{~h}$ and $\mathrm{a}>8$-fold increase in expression by the end of the regenerative time course.

$A T O H 1$, like HES5, is abundant within the regenerative transcriptome. It exhibits an $\sim 2$-fold increase in abundance over the time course with dips at 54 and $120 \mathrm{~h}$ (Fig. 7C). The latter is coincident with the time period when cell division is ceasing and hair cell differentiation is occurring. This pattern of ATOH1 expression is highly correlated with expression of the HEYL gene (hairy/enhancer-of-split related with YRPW motif-like). This coexpression has not been previously described and our observation suggests that a possible upstream coregulator of these two bHLH genes may exist within the regenerating utricle sensory epithelia. One downstream target of ATOH1 is HES6 (Qian et al., 2006), which exhibits much larger fold changes than $A T O H 1$, reaching a 10 -fold increase in expression relative to the controls at $72 \mathrm{~h}$ (Fig. $7 C$ ). It is interesting that the drop in HES5 expression at $54 \mathrm{~h}$ does not correlate with any corresponding major increase in ATOH1 expression (a known repressor of HES5). Therefore, some effector(s) other than ATOH1 may downregulate HES5 expression at this time point.

Together, these observations highlight several coordinate patterns of gene expression that involve previously unexplored components of $\mathrm{NOTCH}$ signaling. They also point to a highly punctuated switch occurring in $\mathrm{NOTCH}$ signaling in the $\sim 48-72 \mathrm{~h}$ window of regeneration consistent with phenotypic conversion.$$
\leftarrow
$$

Blue circles denote additional genes within the differentially expressed subset. Black circles denote genes that are detectable but not differentially expressed. Black lines denote interactions between genes/gene products. B, Network of interactions between some of the transcription factor genes within clusters 13 and 15 (Fig. 8) exhibiting a dip in expression at $120 \mathrm{~h}$. This includes only genes that are detectably expressed in the regenerative time course. Color coding as in $\boldsymbol{A}$ except red genes are differentially expressed transcription factors in these clusters.
} 

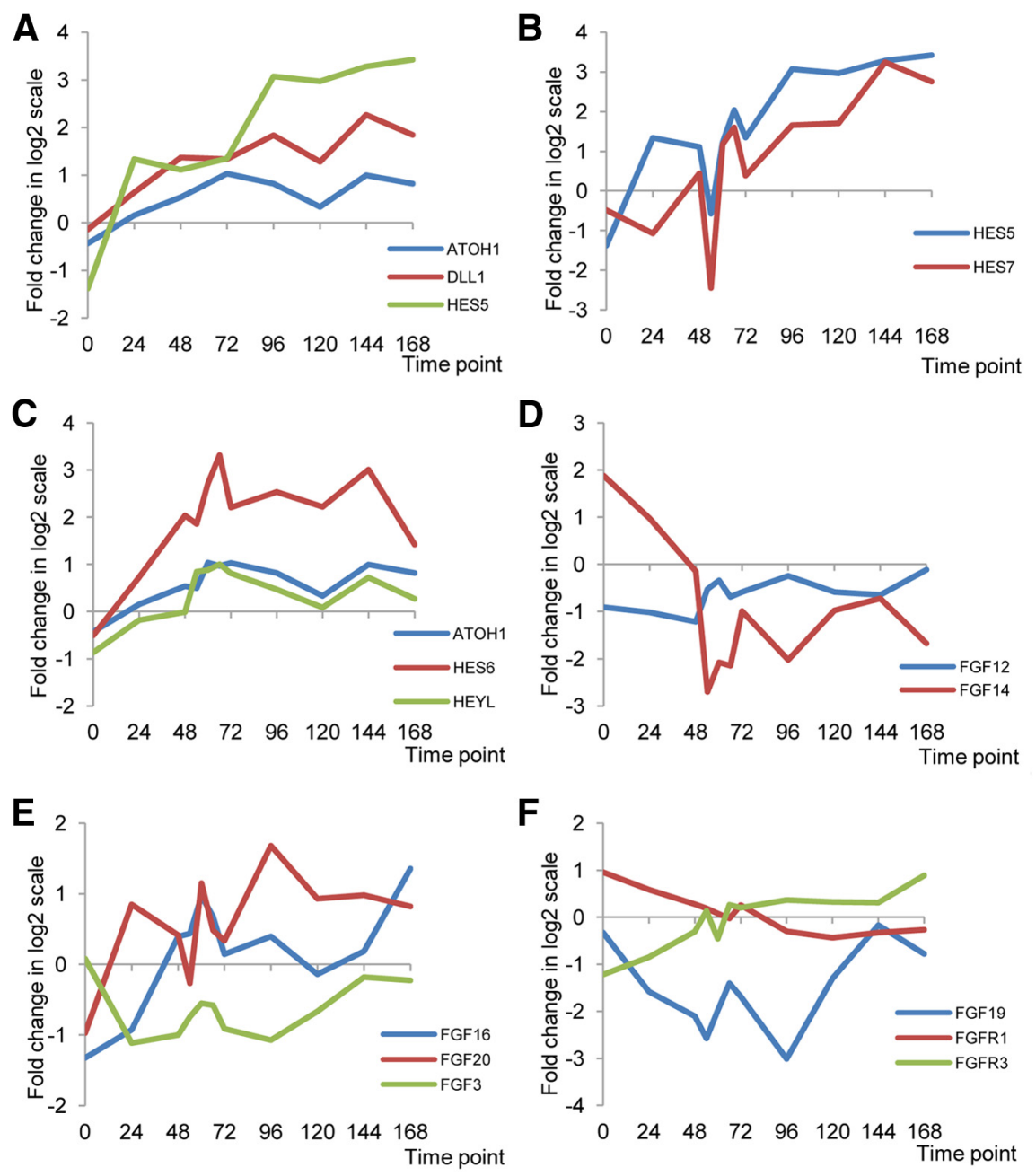

Figure 7. Changes in specific components of the NOTCH and FGF signaling pathways during regeneration. The $x$-axis indicates individual time points. The $y$-axis shows the fold change of streptomycin-treated versus control samples on a $\log _{2}$ scale. $\boldsymbol{A}$, Expression profiles of $A T O H 1, D L L 1$, and $H E S 5$ at $24 \mathrm{~h}$ intervals across the $168 \mathrm{~h}$ time course. $\boldsymbol{B}$, Expression profiles of $H E S 5$ and $H E S 7$ with the addition of detailed sampling within the $48-72 \mathrm{~h}$ period at $6 \mathrm{~h}$ intervals. C, Expression profiles of $A T O H 1, H E S 6$, and $H E Y L$. $D$, Expression profiles of differentially expressed intracrine FGFs (FGF12 and FGF14). E, Expression profiles of differentially expressed paracrine FGFs (FGF3, FGF16, and FGF20). $\boldsymbol{F}$, Expression profiles of FGF19, FGFR1, and FGFR3.

\section{FGF signaling}

The FGF family and their receptors are key regulators of development in the inner ear (Schimmang, 2007). Twelve members of the FGF gene family are detectably expressed in our dataset. Of these, six (FGF3, FGF12, FGF14, FGF16, FGF19, and FGF20) are differentially expressed. FGF3 and FGF20 mouse gene knockouts result in inner ear malformations (Alvarez et al., 2003; Hayashi et al., 2008), but FGF12, FGF14, FGF16, and FGF19 have not yet been investigated in hair cell development or regeneration. Of the five described FGF receptors, we can detect four (FGFR1, FGFR2, FGFR3, and FGFRL1) at above threshold levels, but only FGFR3 passes our filters. In Figure 7, the six FGFs that show large changes in gene expression are shown according to their known modes of action (Itoh and Ornitz, 2008). Two (FGF12 and FGF14) are intracrine FGFs that appear to operate as intracellular signaling molecules. They may have some functional redundancy, but in this case their gene expression patterns are quite different. FGF12 is initially downregulated (Fig. 7D) and recovers by $168 \mathrm{~h}$. A more dramatic pattern is seen for FGF14, which is initially upregulated by 4 -fold. It decreases in abundance, remaining downregulated throughout the remainder of the time course. There is a well established connection between FGF14 and the regulation of voltage-gated sodium (NAv) channel function (Lou et al., 2005), suggesting that the early stages of the regenerative time course may be a time of rapidly changing channel function in the supporting cells.

The FGF3, FGF16, and FGF20 genes encode classic paracrine FGFs that act through FGFRs. Of these, FGF16 and FGF20 are most closely related (Itoh and Ornitz, 2008). These gene expression patterns are shown in Figure $7 E$ and some similarities can be seen. They both exhibit fluctuations in an overall upward direction, diverging at the end of the time course. In contrast, FGF3 is downregulated throughout the regenerative time course and only rebounds at the onset of hair cell differentiation in the 144-168 h time period. The final FGF that passes our filters is FGF19. This is a member of the small family of FGFs that have the ability to act at a distance in an endocrine manner (Itoh and Ornitz, 2008). This gene is dramatically downregulated between 0 and $54 \mathrm{~h}$ (Fig. $7 F$ ) and then exhibits a significant rebound in expression at 66-72 $\mathrm{h}$, followed by an 8 -fold drop in expression at $96 \mathrm{~h}$ and a rebound again at $144 \mathrm{~h}$. This interesting pattern of gene expression parallels the two phases of hair cell production and suggests that this FGF may be an interesting candidate for functional follow-up.

The final components shown in Figure $7 F$ are FGFR1 and FGFR3. FGFR1 did not pass our filters, but only narrowly. It is $\sim 10$-fold higher in transcript abundance than FGFR3 and displays an expression pattern that is almost the reciprocal of FGFR3, starting 2-fold higher than controls and ending slightly lower, whereas FGFR3 starts 2-fold lower and ends the time course 2-fold higher than controls.

Although complex, the expression patterns of FGFs and FGFRs described here suggest a functional role for FGF signaling in utricular regeneration. Prior studies have shown that FGF20 interacts preferentially with FGFR3 (Itoh and Ornitz, 2011). Our data indicate that both FGF20 and FGFR3 transcripts are low shortly after ototoxic injury (when proliferation levels are high), but then increase later when regenerative proliferation stops and hair cell differentiation occurs. One interpretation of these findings is that FGF20 signaling may inhibit (rather than promote) supporting cell proliferation. To test this, we treated cultured utricles $(n=11)$ with exogenous FGF20 immediately after ototoxic injury. Cultures were maintained for $48 \mathrm{~h}$ and a proliferation index was measured by BrdU incorporation. Control cultures did not receive FGF20. Results indicated that FGF20 significantly reduced supporting cell proliferation $\left(32.5 \pm 9.9 \mathrm{BrdU}\right.$-labeled cells $/ 10,000 \mu \mathrm{m}^{2}$ in control specimens vs $12.3 \pm 9.6$ labeled cells $/ 10,000 \mu \mathrm{m}^{2}$ in FGF20-treated specimens, $p<0.0001)$. In contrast, treatment 

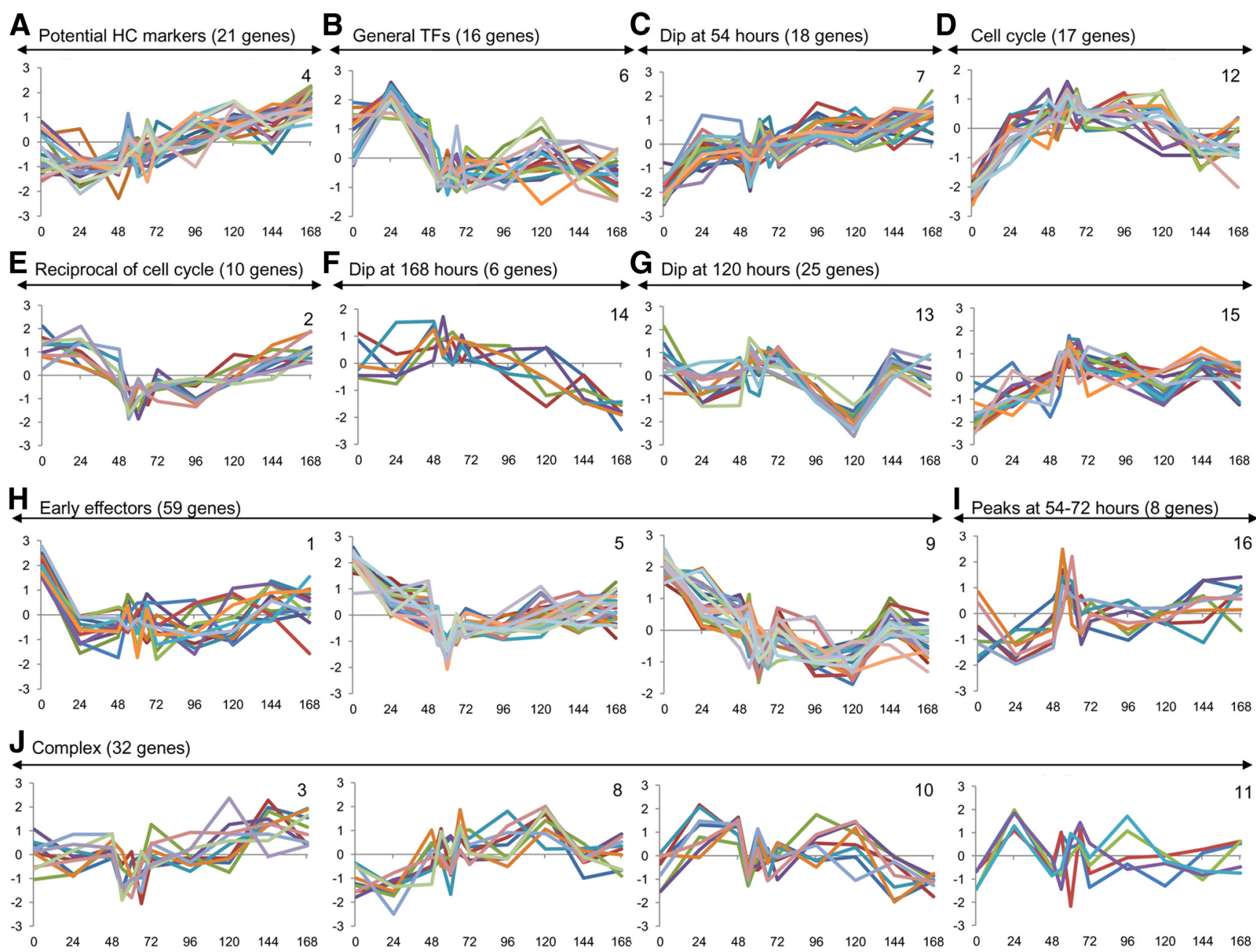

Figure 8. Gene expression profiles of differentially expressed transcription factors clustered into 16 centroids by SOMs. The 212 differentially expressed transcription factors were grouped by SOMs (Partek) according to their expression patterns. The $x$-axis of each group indicates individual time points. The $y$-axis shows the normalized fold change on a log ${ }_{2}$ scale. Centroids were then manually grouped according to their shared overall expression patterns. See Differentially expressed transcription factor genes in the Results for a description of patterns $\boldsymbol{A}-\boldsymbol{J}$.

for $48 \mathrm{~h}$ with an inhibitor of FGF receptors (SU5402) had no significant impact on proliferation (33.7 \pm 13.2 labeled cells/ $10,000 \mu \mathrm{m}^{2}$ in SU5402-treated cultures vs $26.8 \pm 6.7$ labeled cells $/ 10,000 \mu \mathrm{m}^{2}$ in control cultures, $p=0.21$ ). Notably, application of FGF2 (the expression levels of which did not show significant changes in the regenerating utricle) can also inhibit supporting cell proliferation (Oesterle et al., 2000). Together, these data suggest that $F G F$ signaling (specifically FGF20) may be a negative regulator of regenerative proliferation in the avian utricle.

\section{Differentially expressed transcription factor genes}

Among the differentially expressed genes, we were interested in identifying those encoding transcription factors that are potential key regulators of the regenerative program. We compiled a nonredundant list of transcription factors from three databases and recent publications (Thomas et al., 2003; Messina et al., 2004; Fulton et al., 2009; Vaquerizas et al., 2009; Ravasi et al., 2010; Zhang et al., 2012) and compared that with our list of differentially expressed genes. In this way, we identified 212 differentially expressed transcription factors (several of which are highlighted in Table 2). The vast majority of these have never been investigated in hair cell regeneration or in the development of the inner ear.
We next derived 16 SOMs from these gene expression profiles to identify distinct expression patterns. These are shown in Figure 8 and fall into nine patterns, with one additional group of four "complex" centroids (Fig. $8 J$ ).

Figure $8 \mathrm{~A}$ shows a centroid enriched for hair-cell-specific transcription factors. These comprise 21 genes and include known hair-cell-specific transcription factor genes (POU4F3, GFI1, and LHX3) and others identified in this study (ANKRD5, $D P F 3, N F A T C 1$, and SKOR1). The hair cell expression filters that we imposed above on the total gene set were quite conservative. Therefore, the additional 15 transcription factors within this group may represent additional hair-cell-specific transcription factors. Figure $8 C$ is enriched for genes that parallel the HES5 and HES7 patterns of gene expression with changes in expression coincident with phenotypic conversion listed in Table 2. Particularly interesting in this cluster is the BTG1 gene, which appears to have antiproliferative and prodifferentiation functions (Rouault et al., 1992; Rodier et al., 1999), the interferon regulatory factor 4 (IRF4) gene (Grossman et al., 1996), and the Cbp/ p300-interacting transactivator (CITED4; Bragança et al., 2002), none of which have been previously investigated or implicated in sensory epithelia regeneration. Figure $8 I$ shows eight genes that exhibit peaks of expression in the 54-72 $\mathrm{h}$ window of the time course. These are attractive candidates for playing roles in the 
phenotypic conversion process. Among the most highly expressed in this class are two implicated in the NOTCH pathway: MAMLD1 (mastermind-like, a coactivator in NOTCH signaling) and RBPJL (similar to the RBPJ gene in NOTCH signaling; Table 2 ). Figure $8 G$ shows clusters that share a pronounced drop at $120 \mathrm{~h}$ coincident with cell cycle cessation. Seven of these 25 genes, including $\mathrm{NOTCH} 1$, show evidence for network interactions and tie together a predicted network of 138 genes that are detectable in the time course (Fig. $6 B$ ). This network provides strong confirmatory evidence that these genes are functionally connected and provides insights into their possible downstream effectors. The genes shown in Figure $8 G$ are also of particular note because they contain seven of the 20 helix loop helix (HLH) or basic helix loop helix (bHLH) family of genes present in the list of differentially expressed transcription factors. Of these, five (ATOH1, HEYL, ID4, ID2, and ID1) are highly correlated and are particularly interesting. The ID gene family consists of four HLH paralogs (ID1-ID4). They encode dominant-negative inhibitors of bHLH genes such as ATOH1. ID1, ID4, and ID2 all show a strong positive correlation with $A T O H 1$ expression during utricle sensory epithelia regeneration. A preliminary computational analysis of the promoter-proximal regions of these genes did not reveal any shared DNA sequence motifs (data not shown). Nevertheless, coordinate regulation through more distal regulatory elements cannot be discounted. ID genes are among the most highly expressed transcription factor genes in the regenerating sensory epithelia. These observations suggest that $I D$ proteins are present at very high levels and are probably in vast excess compared with many of their targets (activating bHLH proteins). It is clear that the pattern of $A T O H 1$ and $I D$ gene expression in the regenerating avian utricle sensory epithelia is highly correlated and thus very different from that described for the mouse auditory sensory epithelia (Jones et al., 2006), in which these genes appear to show reciprocal patterns of expression. These observations suggest that different regulatory circuits may operate in the auditory and vestibular epithelia to modulate the activity of $A T O H 1$ and additional bHLH genes.

\section{Discussion}

Here, we have derived the most comprehensive description to date of the mRNA transcriptome during hair cell regeneration. Our previous study of this process (Hawkins et al., 2007) focused only on the first $48 \mathrm{~h}$ of regeneration and solely upon transcription factor genes (many of which at that time had no clear chicken orthologs). A total of 87 transcription factor genes identified in those earlier expression profiles overlap with the present study. Clearly, our new dataset represents a greatly expanded, much more complete, accurate, and highly complex genetic toolbox for investigations of sensory regeneration and for comparisons with the nonregenerative mammalian inner ear. In particular, in the present study, we have emphasized patterns and pathways of gene expression that correlate well with three phenotypes of the regenerative sensory epithelia; DNA replication/cell cycle control, phenotypic conversion, and regenerative proliferation. We also identified additional patterns that we predict are enriched for genes affecting processes such as apoptosis, RNA processing, and components of the hair cell transcriptome (Fig. 1). In the latter case, we tested our prediction directly by determining the hair cell specificity of three randomly chosen genes in this subset by immunohistochemistry. As predicted, all of these showed hair cell specificity.

A surprising observation from our dataset is the highly punctuated nature of the events that occur across this time course.
DNA replication and the expression of cell cycle components appear quite synchronous and provide patterns of gene expression that are highly diagnostic. Likewise, the process of phenotypic conversion appears to occur in the $48-72 \mathrm{~h}$ time period and is likely to be reflected in highly dynamic patterns of expression for many genes in this time window, particularly many of the known components of Notch signaling. The high levels of proliferation observed in the utricle suggest that most new hair cells are created by cell division, rather than through phenotypic conversion. Therefore, signals that are entirely specific to the new hair cell population in this time window appear minor when this dilution effect is not taken into account. With that in mind, if the overall 2-fold increase in $A T O H 1$ expression from $60 \mathrm{~h}$ through $72 \mathrm{~h}$ is hair cell specific, then this would reflect a very large induction of this transcription factor. In that same context, the changes in HES5 (considered to be a supporting cell marker), if they are occurring in all of the supporting cells in this same time frame, would be relatively smaller compared with $A T O H 1$. It remains to be seen whether the additional dynamically expressed genes in this time interval mark supporting cells, new hair cells, or cell subpopulations.

We anticipate that this resource will prove immediately useful as a source of components to test systematically by knock-downs or overexpression analyses (Alvarado et al., 2011). We extracted considerable pathway and network annotations to enhance data accessibility and utility. Several of these pathways have been implicated previously in inner ear sensory epithelia biology. However, our annotations now identify the exact individual components within these pathways, their relative transcript abundances, and changes in gene expression. In some cases, this reveals surprising pathways and genes that have not been implicated previously in sensory epithelia function or regeneration. As noted in Notch pathways in the Results, above, several surprising components of Notch signaling (e.g., HES7) are present in our dataset or exhibit interesting patterns of coordinate expression (e.g., HEYL and $A T O H 1)$. In addition to the many transcription factors we have identified that have never been implicated in inner ear development or regeneration, there are numerous other surprising new candidates. Some notable examples occur among members of what appears to be the regenerative "secretome." Prominent among these is leukemia inhibitory factor (LIF), a cytokine capable of inducing differentiation in numerous cell types, including leukemic and neuronal cells (Chen et al., 2010; Mathieu et al., 2012). LIF transcripts, along with several additional components of the LIF signaling pathway (Ip et al., 1992), are abundant and differentially expressed during sensory epithelia regeneration. The regenerating pure avian sensory epithelium also produces a surprisingly complex mixture of what have been historically regarded as growth and differentiation factors of the hematopoietic system. These inflammatory modulators have not yet been investigated in inner ear sensory epithelia. For example, we observed robust expression of the chemokine CXCL14, which is found in zebrafish lateral line neuromasts (Long et al., 2000). Although the function of CXCL14 is not known, it is expressed in the chick utricle throughout the regenerative time course and is among the most abundant transcripts. Additional chemokines, cytokines, and their receptors are also differentially expressed in our dataset, including CCL17, CCL4, CXCL12, and CXCR4. In addition, we observed 14 interleukins or interleukin receptors within our differentially expressed dataset. Most prominent among these are IL18,IL16, IL22RA1, and IL6. Of these, IL6 is 
produced by many different epithelia and plays a role in epithelial-stromal interactions (Elner et al., 1992; Notara et al., 2010). All of these are attractive candidates for functional follow-up. Finally, our observations suggest novel roles for FGF signaling in the regenerating utricle. We observed robust expression of the intracrine factors FGF12 and FGF14, the function of which has not been investigated previously in the ear. In addition, our data suggest that FGF20, which regulates the differentiation of outer hair cells in the developing cochleae of mammals (Huh et al., 2012), may act to suppress regenerative proliferation in the chick utricle. Notably, enhanced expression of FGF20 begins at $\sim 3-4 \mathrm{~d}$ after ototoxic injury as regenerative proliferation is terminating and replacement hair cells are beginning to differentiate. It is possible that expression of FGF20 serves as a "stop" signal in the proliferative process.

One motivation for conducting this study was to identify the best candidates for controlling the regenerative cascade in birds and possibly affecting regeneration in the mammalian inner ear. In particular, the transcription factor genes we have highlighted here should provide useful starting points in deciphering the exact genetic circuitry of hair cell regeneration. This resource may also prove useful as a source of candidate genes for studies of other sustentacular stem cell populations that give rise to neurons and sensory cells in many nonmammalian vertebrates.

\section{Notes}

Supplemental material for this article is available at https://workspace. imperial.ac.uk/medicine/Public/PWPs/HimaAnbunathan/Ku.et.al.Archive. zip. Ten tables describing qRT-PCR, complete dataset, clustering, and pathway analysis. This material has not been peer reviewed.

\section{References}

Alvarado DM, Hawkins RD, Bashiardes S, Veile RA, Ku YC, Powder KE, Spriggs MK, Speck JD, Warchol ME, Lovett M (2011) An RNA interference-based screen of transcription factor genes identifies pathways necessary for sensory regeneration in the avian inner ear. J Neurosci 31:4535-4543. CrossRef Medline

Alvarez Y, Alonso MT, Vendrell V, Zelarayan LC, Chamero P, Theil T, Bösl MR, Kato S, Maconochie M, Riethmacher D, Schimmang T (2003) Requirements for FGF3 and FGF10 during inner ear formation. Development 130:6329-6338. CrossRef Medline

Avraham KB, Hasson T, Steel KP, Kingsley DM, Russell LB, Mooseker MS, Copeland NG, Jenkins NA (1995) The mouse Snell's waltzer deafness gene encodes an unconventional myosin required for structural integrity of inner ear hair cells. Nat Genet 11:369-375. CrossRef Medline

Bessho Y, Sakata R, Komatsu S, Shiota K, Yamada S, Kageyama R (2001) Dynamic expression and essential functions of Hes7 in somite segmentation. Genes Dev 15:2642-2647. CrossRef Medline

Blanchfield BB, Feldman JJ, Dunbar JL, Gardner EN (2001) The severely to profoundly hearing-impaired population in the United States: prevalence estimates and demographics. J Am Acad Audiol 12:183189. Medline

Bragança J, Swingler T, Marques FI, Jones T, Eloranta JJ, Hurst HC, Shioda T, Bhattacharya S (2002) Human CREB-binding protein/p300-interacting transactivator with ED-rich tail (CITED) 4 , a new member of the CITED family, functions as a co-activator for transcription factor AP-2. J Biol Chem 277:8559-8565. CrossRef Medline

Chen HC, Ma HI, Sytwu HK, Wang HW, Chen CC, Liu SC, Chen CH, Chen HK, Wang CH (2010) Neural stem cells secrete factors that promote auditory cell proliferation via a leukemia inhibitory factor signaling pathway. J Neurosci Res 88:3308-3318. CrossRef Medline

Corwin JT, Cotanche DA (1988) Regeneration of sensory hair cells after acoustic trauma. Science 240:1772-1774. CrossRef Medline

Cotanche DA, Lee KH, Stone JS, Picard DA (1994) Hair cell regeneration in the bird cochlea following noise damage or ototoxic drug damage. Anat Embryol (Berl) 189:1-18. Medline

Duncan LJ, Mangiardi DA, Matsui JI, Anderson JK, McLaughlin-Williamson
K, Cotanche DA (2006) Differential expression of unconventional myosins in apoptotic and regenerating chick hair cells confirms two regeneration mechanisms. J Comp Neurol 499:691-701. CrossRef Medline

Elner VM, Scales W, Elner SG, Danforth J, Kunkel SL, Strieter RM (1992) Interleukin-6 (IL-6) gene expression and secretion by cytokinestimulated human retinal pigment epithelial cells. Exp Eye Res 54:361368. CrossRef Medline

Faúndez V, Horng JT, Kelly RB (1998) A function for the AP3 coat complex in synaptic vesicle formation from endosomes. Cell 93:423-432. CrossRef Medline

Forge A, Li L, Corwin JT, Nevill G (1993) Ultrastructural evidence for hair cell regeneration in the mammalian inner ear. Science 259:1616-1619. CrossRef Medline

Fulton DL, Sundararajan S, Badis G, Hughes TR, Wasserman WW, Roach JC, Sladek R (2009) transcription factorCat: the curated catalog of mouse and human transcription factors. Genome Biol 10:R29. CrossRef Medline

Girod DA, Duckert LG, Rubel EW (1989) Possible precursors of regenerated hair cells in the avian cochlea following acoustic trauma. Hear Res 42:175-194. CrossRef Medline

Goodyear RJ, Gates R, Lukashkin AN, Richardson GP (1999) Hair-cell numbers continue to increase in the utricular macula of the early posthatch chick. J Neurocytol 28:851-861. CrossRef Medline

Gratzner HG (1982) Monoclonal antibody to 5-bromo- and 5-iododeoxyuridine: A new reagent for detection of DNA replication. Science 218:474475. CrossRef Medline

Grossman A, Mittrücker HW, Nicholl J, Suzuki A, Chung S, Antonio L, Suggs S, Sutherland GR, Siderovski DP, Mak TW (1996) Cloning of human lymphocyte-specific interferon regulatory factor (hLSIRF/hIRF4) and mapping of the gene to 6p23-p25. Genomics 37:229-233. CrossRef Medline

Hawkins RD, Bashiardes S, Powder KE, Sajan SA, Bhonagiri V, Alvarado DM, Speck J, Warchol ME, Lovett M (2007) Large scale gene expression profiles of regenerating inner ear sensory epithelia. PLoS One 2:e525. CrossRef Medline

Hayashi T, Ray CA, Bermingham-McDonogh O (2008) Fgf20 is required for sensory epithelial specification in the developing cochlea. J Neurosci 28:5991-5999. CrossRef Medline

Heitzler P, Bourouis M, Ruel L, Carteret C, Simpson P (1996) Genes of the Enhancer of split and achaete-scute complexes are required for a regulatory loop between Notch and Delta during lateral signalling in Drosophila. Development 122:161-171. Medline

Herget M, Scheibinger M, Guo Z, Jan TA, Adams CM, Cheng AG, Heller S (2013) A simple method for purification of vestibular hair cells and nonsensory cells, and application for proteomic analysis. PLoS One 8:e66026. CrossRef Medline

Hertzano R, Elkon R, Kurima K, Morrisson A, Chan SL, Sallin M, Biedlingmaier A, Darling DS, Griffith AJ, Eisenman DJ, Strome SE (2011) Cell type-specific transcriptome analysis reveals a major role for Zeb1 and miR-200b in mouse inner ear morphogenesis. PLoS Genet 7:e1002309. CrossRef Medline

Hirata H, Yoshiura S, Ohtsuka T, Bessho Y, Harada T, Yoshikawa K, Kageyama R (2002) Oscillatory expression of the bHLH factor Hes1 regulated by a negative feedback loop. Science 298:840-843. CrossRef Medline

da Huang W, Sherman BT, Lempicki RA (2009) Systematic and integrative analysis of large gene lists using DAVID bioinformatics resources. Nat Protoc 4:44-57. CrossRef Medline

Huh SH, Jones J, Warchol ME, Ornitz DM (2012) Differentiation of the lateral component of the cochlea requires a temporally restricted FGF20 signal. PLoS Biology 10:e1001231. CrossRef Medline

Ip NY, Nye SH, Boulton TG, Davis S, Taga T, Li Y, Birren SJ, Yasukawa K, Kishimoto T, Anderson DJ, Stahl N, Yancopoulos GD (1992) CNTF and LIF act on neuronal cells via shared signaling pathways that involve the IL-6 signal transducing receptor component gp130. Cell 69:1121-1132. CrossRef Medline

Itoh N, Ornitz DM (2008) Functional evolutionary history of the mouse Fgf gene family. Dev Dyn 237:18-27. CrossRef Medline

Itoh N, Ornitz DM (2011) Fibroblast growth factors: from molecular evolution to roles in development, metabolism and disease. J Biochem 149: 121-130. CrossRef Medline

Jones JM, Montcouquiol M, Dabdoub A, Woods C, Kelley MW (2006) Inhibitors of differentiation and DNA binding (Ids) regulate Math1 and 
hair cell formation during the development of the organ of Corti. J Neurosci 26:550-558. CrossRef Medline

Kohonen T (1982) Self-organized formation of topologically correct feature maps. Biological Cybernetics 43:59-69. CrossRef

Kusano S, Raab-Traub N (2002) I-mfa domain proteins interact with Axin and affect its regulation of the Wnt and c-Jun $\mathrm{N}$-terminal kinase signaling pathways. Mol Cell Biol 22:6393-6405. CrossRef Medline

Lanford PJ, Lan Y, Jiang R, Lindsell C, Weinmaster G, Gridley T, Kelley MW (1999) Notch signalling pathway mediates hair cell development in mammalian cochlea. Nat Genet 21:289-292. CrossRef Medline

Lanford PJ, Shailam R, Norton CR, Gridley T, Kelley MW (2000) Expression of Math1 and HES5 in the cochleae of wildtype and Jag2 mutant mice. J Assoc Res Otolaryngol 1:161-171. CrossRef Medline

Lindsell CE, Boulter J, diSibio G, Gossler A, Weinmaster G (1996) Expression patterns of Jagged, Delta1, Notch1, Notch2, and Notch3 genes identify ligand-receptor pairs that may function in neural development. Mol Cell Neurosci 8:14-27. CrossRef Medline

Long Q, Quint E, Lin S, Ekker M (2000) The zebrafish scyba gene encodes a novel CXC-type chemokine with distinctive expression patterns in the vestibulo-acoustic system during embryogenesis. Mech Dev 97:183-186. CrossRef Medline

Lou JY, Laezza F, Gerber BR, Xiao M, Yamada KA, Hartmann H, Craig AM, Nerbonne JM, Ornitz DM (2005) Fibroblast growth factor 14 is an intracellular modulator of voltage-gated sodium channels. J Physiol 569: 179-193. CrossRef Medline

Marazita ML, Ploughman LM, Rawlings B, Remington E, Arnos KS, Nance WE (1993) Genetic epidemiological studies of early-onset deafness in the U.S. school-age population. Am J Med Genet 46:486-491. CrossRef Medline

Mathieu ME, Saucourt C, Mournetas V, Gauthereau X, Thézé N, Praloran V, Thiébaud P, Bouf H (2012) LIF-dependent signaling: new pieces in the Lego. Stem Cell Rev 8:1-15. CrossRef Medline

Matsui JI, Ogilvie JM, Warchol ME (2002) Inhibition of caspases prevents ototoxic and ongoing hair cell death. J Neurosci 22:1218-1227. Medline

McDermott BM Jr, Baucom JM, Hudspeth AJ (2007) Analysis and functional evaluation of the hair-cell transcriptome. Proc Natl Acad Sci U S A 104:11820-11825. CrossRef Medline

Messina DN, Glasscock J, Gish W, Lovett M (2004) An ORFeome-based analysis of human transcription factor genes and the construction of a microarray to interrogate their expression. Genome Res 14:2041-2047. CrossRef Medline

Meyers JR, Corwin JT (2008) Morphological correlates of regeneration and repair in the inner ear. In: Hair cell regeneration, repair, and protection (Salvi RJ, Popper AN, Fay RR, eds.), pp 39-75. New York: Springer.

Morrison A, Hodgetts C, Gossler A, Hrabé de Angelis M, Lewis J (1999) Expression of Delta1 and Serratel (Jagged1) in the mouse inner ear. Mech Dev 84:169-172. CrossRef Medline

Mortazavi A, Williams BA, McCue K, Schaeffer L, Wold B (2008) Mapping and quantifying mammalian transcriptomes by RNA-Seq. Nat Methods 5:621-628. CrossRef Medline

Newman LS, McKeever MO, Okano HJ, Darnell RB (1995) Beta-NAP, a cerebellar degeneration antigen, is a neuron-specific vesicle coat protein. Cell 82:773-783. CrossRef Medline

Niwa Y, Shimojo H, Isomura A, González A, Miyachi H, Kageyama R (2011) Different types of oscillations in Notch and Fgf signaling regulate the spatiotemporal periodicity of somitogenesis. Genes Dev 25:1115-1120. CrossRef Medline

Notara M, Shortt AJ, Galatowicz G, Calder V, Daniels JT (2010) IL6 and the human limbal stem cell niche: a mediator of epithelial-stromal interaction. Stem Cell Res 5:188-200. CrossRef Medline

Oesterle EC, Bhave SA, Coltrera MD (2000) Basic fibroblast growth factor inhibits cell proliferation in cultured avian inner ear sensory epithelia. J Comp Neurol 424:307-326. CrossRef Medline

Qian D, Radde-Gallwitz K, Kelly M, Tyrberg B, Kim J, Gao WQ, Chen P (2006) Basic helix-loop-helix gene Hes6 delineates the sensory hair cell lineage in the inner ear. Dev Dyn 235:1689-1700. CrossRef Medline

Ravasi T, Suzuki H, Cannistraci CV, Katayama S, Bajic VB, Tan K, Akalin A, Schmeier S, Kanamori-Katayama M, Bertin N, Carninci P, Daub CO, Forrest AR, Gough J, Grimmond S, Han JH, Hashimoto T, Hide W, Hofmann O, Kamburov A, Kaur M, Kawaji H, Kubosaki A, Lassmann T, van Nimwegen E, MacPherson CR, Ogawa C, Radovanovic A, Schwartz A, Teasdale RD, Tegnér J, Lenhard B, Teichmann SA, Ara- kawa T, Ninomiya N, Murakami K, Tagami M, Fukuda S, Imamura K, Kai C, Ishihara R, Kitazume Y, Kawai J, Hume DA, Ideker T, Hayashizaki Y (2010) An atlas of combinatorial transcriptional regulation in mouse and man. Cell 140:744-752. CrossRef Medline

Reimand J, Arak T, Vilo J (2011) g:Profiler-a web server for functional interpretation of gene lists (2011 update). Nucleic Acids Res 39:W307-315. CrossRef Medline

Roberson DW, Alosi JA, Cotanche DA (2004) Direct transdifferentiation gives rise to the earliest new hair cells in regenerating avian auditory epithelium. J Neurosci Res 78:461-471. CrossRef Medline

Rodier A, Marchal-Victorion S, Rochard P, Casas F, Cassar-Malek I, Rouault JP, Magaud JP, Mason DY, Wrutniak C, Cabello G (1999) BTG1: a triiodothyronine target involved in the myogenic influence of the hormone. Exp Cell Res 249:337-348. CrossRef Medline

Rouault JP, Rimokh R, Tessa C, Paranhos G, Ffrench M, Duret L, Garoccio M, Germain D, Samarut J, Magaud JP (1992) BTG1, a member of a new family of antiproliferative genes. EMBO J 11:1663-1670. Medline

Ryals BM, Rubel EW (1988) Hair cell regeneration after acoustic trauma in adult Coturnix quail. Science 240:1774-1776. CrossRef Medline

Schimmang T (2007) Expression and functions of FGF ligands during early otic development. Int J Dev Biol 51:473-481. CrossRef Medline

Sever S (2002) Dynamin and endocytosis. Curr Opin Cell Biol 14:463-467. CrossRef Medline

Shin JB, Krey, JF, Hassan A, Metlagel Z, Tauscher AN, Paga JM, Sherman NE, Jeffrey ED, Spinelli KJ, Zhao H, Wilmarth, PA, Choi D, David LL, Auer M, Barr-Gillespie PG (2013) Moleular architecture of the chick vestibular hair bundle. Nat Neurosci 16:365-374. CrossRef Medline

Sinkkonen ST, Chai R, Jan TA, Hartman BH, Laske RD, Gahlen F, Sinkkonen W, Cheng AG, Oshima K, Heller S (2011) Intrinsic regenerative potential of murine cochlear supporting cells. Sci Rep 1:26. CrossRef Medline

Smoot ME, Ono K, Ruscheinski J, Wang PL, Ideker T (2011) Cytoscape 2.8: new features for data integration and network visualization. Bioinformatics 27:431-432. CrossRef Medline

Stone JS, Cotanche DA (1994) Identification of the timing of S phase and the patterns of cell proliferation during hair cell regeneration in the chick cochlea. J Comp Neurol 341:50-67. CrossRef Medline

Stone JS, Rubel EW (1999) Deltal expression during avian hair cell regeneration. Development 126:961-973. Medline

Thomas PD, Kejariwal A, Campbell MJ, Mi H, Diemer K, Guo N, Ladunga I, Ulitsky-Lazareva B, Muruganujan A, Rabkin S, Vandergriff JA, Doremieux O (2003) PANTHER: a browsable database of gene products organized by biological function, using curated protein family and subfamily classification. Nucleic Acids Res 31:334-341. CrossRef Medline

Trapnell C, Pachter L, Salzberg SL (2009) TopHat: discovering splice junctions with RNA-Seq. Bioinformatics 25:1105-1111. CrossRef Medline

Vaquerizas JM, Kummerfeld SK, Teichmann SA, Luscombe NM (2009) A census of human transcription factors: function, expression and evolution. Nat Rev Genet 10:252-263. CrossRef Medline

Warchol ME (1999) Immune cytokines and dexamethasone influence sensory regeneration in the avian vestibular periphery. J Neurocytol 28:889 900. CrossRef Medline

Warchol ME, Corwin JT (1996) Regenerative proliferation in organ cultures of the avian cochlea: identification of the initial progenitors and determination of the latency of the proliferative response. J Neurosci 16:5466-5477. Medline

Warchol ME, Montcouquiol M (2010) Maintained expression of the planar cell polarity molecule Vangl2 and reformation of hair cell orientation in the regenerating inner ear. J Assoc Res Otolaryngol 11:395-406. CrossRef Medline

Warchol ME, Lambert PR, Goldstein BJ, Forge A, Corwin JT (1993) Regenerative proliferation in inner ear sensory epithelia from adult guinea pigs and humans. Science 259:1619-1622. CrossRef Medline

Wiejak J, Wyroba E (2002) Dynamin: characteristics, mechanism of action and function. Cell Mol Biol Lett 7:1073-1080. Medline

Zhang HM, Chen H, Liu W, Liu H, Gong J, Wang H, Guo AY (2012) Animal TFDB: a comprehensive animal transcription factor database. Nucleic Acids Res 40:D144-D149. CrossRef Medline

Zine A, Aubert A, Qiu J, Therianos S, Guillemot F, Kageyama R, de Ribaupierre F (2001) Hes1 and Hes5 activities are required for the normal development of the hair cells in the mammalian inner ear. J Neurosci 21: 4712-4720. Medline 